\title{
Purchasing Power Parity: A Unit Root, Cointegration and VAR Analysis in Emerging and Advanced Countries
}

\author{
Georgios Loukopoulos (Corresponding author) \\ University of Patras, Department of Business Administration, Greece \\ University Campus, Rio, Achaia, 26504, Greece \\ E-mail: geolouk@live.com \\ Dimitrios Antonopoulos \\ University of Patras, Department of Business Administration, Greece \\ University Campus, Rio, Achaia, 26504, Greece \\ E-mail: dim.ant@hotmail.com
}

Received: March 2, 2015 Accepted: March 25, 2015

doi:10.5296/ber.v5i1.7177 URL: http://dx.doi.org/10.5296/ber.v5i1.7177

\begin{abstract}
The purpose of this study is to investigate the validity of the absolute version of the purchasing power parity (PPP) of a sample of four advanced and four emerging countries covering the period from 1993 to 2014. To examine the existence of PPP we apply the Augmented Dickey-Fuller, DF-GLS and KPSS tests for non-stationarity, and the Johansen procedure for cointegration between exchange rates and consumer price indices. The impulse response function presents a graphical view which is consistent with impressions from the statistics of stationarity tests. We also employ the variance decomposition method to analyze the movements in the exchange rates and the price indices that are caused by their own shocks, and shocks caused by other variables. With respect to half-life estimates, the results from a shock to the real exchange rate range from 0.81 to 6.45 years (3.23 years on average). Overall, unit root tests show that absolute PPP may not hold, but this depends on the country and the selected method. In contrast, the Johansen approach does not support the existence of
\end{abstract}


PPP for both developed countries and emerging market economies.

Keywords: Purchasing Power Parity, Exchange Rates, Time Series Econometrics

\section{Introduction}

The prevalence of the free exchange rates regime has undoubtedly contributed to the growth of international financial markets, but also to a radical increase in the volatility of exchange rates, undermining the national economic policies and the level of future investments. In this regard, a thorough understanding of the causes and the implications of exchange rate uncertainty is of fundamental importance for the efficiency of money and capital markets, as numerous historical events have illustrated.

The academic literature has devoted a considerable amount of time examining the relationship between exchange rates and fundamental macroeconomic variables, focusing either on the sources of the causal relationship or to an implied level determined by an equilibrium theoretical framework. For instance, Rogoff (1996) and Taylor and Taylor (2004) have debated extensively about the validity of the Purchasing Power Parity.

In this paper we restrict our attention to the existence and the degree of validation of the absolute Purchasing Power Parity (PPP) hypothesis. The motivation for this topic comes from several sources. First, in order to evaluate the validity of previous research findings we employ a sample spanning a longer and more recent time period. Second, we select two groups of countries: emerging and advanced. The first group consists of Mexico, China, Hungary and South Africa and the second one of Germany, Japan, the United Kingdom and Canada. The particular set comprises countries with heterogeneous economic characteristics and covers almost all continents. Finally, we perform a wider range of econometric techniques to gain a more complete picture, which will be discussed in detail in the following sections.

According to the PPP hypothesis, the exchange rate will adjust to equalize the price levels between countries. In detail, the formula of the absolute PPP is:

$$
\mathrm{e}=\mathrm{P} / \mathrm{P}^{*}
$$

where $\mathrm{e}$ is the nominal exchange rate measured in units of domestic currency per unit of foreign currency, $\mathrm{P}$ is the domestic price level and $\mathrm{P}^{*}$ is the foreign price level. Note also that the logarithmic transformation of (1) has the form:

$$
\mathrm{s}=\mathrm{p}-\mathrm{p}^{*}
$$

where $\mathrm{s}, \mathrm{p}, \mathrm{p}^{*}$ are the logarithms of e, P, $\mathrm{P}^{*}$. PPP is often used as a benchmark model which provides a baseline forecast of future exchange rates. Therefore, it can be viewed as a measure of deviations from the equilibrium level. An algebraic manipulation of equation (2) gives: 


$$
\mathrm{q}=\mathrm{s}+\mathrm{p}^{*}-\mathrm{p}
$$

Equation (3) is essentially a logarithmic transformation of the real exchange rate which is defined as the nominal exchange rate multiplied by the ratio of the price levels. Thus, we can directly base our inferences regarding the validity of the absolute PPP by focusing on the time series properties of the real exchange rates.

The statistical tools applied in this study contain unit root tests (i.e., ADF, DF-GLS and KPSS). A complementary approach (half-life) estimates the number of years required to correct 50 percent of deviations from PPP levels resulting from a unit shock response in the levels of the series of the real exchange rates. Furthermore, we perform a long-run relationship test (Johansen approach) and Impulse Response Functions (IRF) coupled with Variance Decomposition in order to observe the effects of a shock in the exchange rate and price indices and to analyze the variance of the variables which are contained in the VAR model.

Our main findings can be outlined as follows. First, the results about the validity of PPP are, as expected, providing non-supporting evidence for all countries, except for Mexico in ADF and the United Kingdom in KPSS tests. Another finding worth mentioning is that despite the fact that Mexico has at most two cointegrating vectors, we reject the hypothesis that PPP holds, based on results from the Vector Error Correction Model (VECM). Finally, the results of Mexico's IRF and Variance Decomposition, contradict with the arguments implied by the absolute PPP.

The remainder of the paper is organized as follows. Section 2 reviews previous literature findings. Section 3 describes the sample, methodology and a discussion of the empirical results. Finally, section 4 concludes the paper.

\section{Literature Review}

A wide range of approaches that test the existence of the PPP hypothesis can be categorized in two parts; initially testing the stationarity of the real exchange rate, and secondly, determining the cointegration relationship among the nominal exchange rate and the relative prices. Results are dependent on the performed methods, the characteristics of the sample, the number of the observations and the macroeconomic variables.

The test results for PPP by McDonald (1993) are encouraging and provide empirical evidence for the existence of purchasing power parity in the long-run. He found evidence that PPP does not hold in its strong form for Canada, France, Germany, Japan and the United Kingdom. Cointegration tests did not support the existence of a long-run equilibrium relationship between the consumer price ratio and nominal exchange rate with US dollar as base currency for any of the five countries.

Froot and Rogoff (1995) thoroughly reviewed literature about PPP. They classified PPP test into three periods. In stage one, they examined the relationship between the nominal exchange rate and price levels and tested whether PPP holds. The tests in the second period 
assumed that beta equals one and tested the stationarity of the real exchange rate. Finally, researchers used cointegration techniques to test a weaker version of PPP.

Kojima (2006) tested the validity of purchasing power parity for Japan and U.S.A. by adopting cointegration test and error correction model. He found strong evidence that asserts the PPP restriction which creates the equilibrium error in the form of a real exchange rate. The last finding is that the IRF of the exchange rate to prices and conversely would imply exchange rates channeling inflation from one country into another.

Also, Acaravci S. K. and Acaravci (2007) used four different panel data unit root tests under a period of sixteen years (1990-2006) with quarterly observations in order to examine the validity of PPP for both developed and emerging countries during the floating exchange rate period. Their empirical results failed to support PPP for both groups of countries.

Another study of Alba and Papell (2007), examined the absolute PPP, using panel data methods, testing for unit roots in the real exchange rates of 84 countries during the floating exchange rate period. The purpose of their study was to move beyond the developed/developing country dichotomy in order to investigate the role of individual country characteristic on PPP. More specifically, they used panel methods based on Levin et al., ADF and Monte Carlo, and found strong evidence of PPP in countries more open to trade, closer to the United States, with lower inflation and moderate nominal exchange rate volatility and with similar economic growth rates as the United States. They concluded that country characteristics can help us to explain both adherence to and deviations from long-run PPP.

In their paper on purchasing power parity for developing and developed countries, Drine and Rault (2007) investigated whether the PPP theory could be used as a criterion to specify the real exchange rate development for a sample of 80 developed and developing countries. Their findings demonstrated that strong form of PPP is verified for OECD countries and weak form of PPP for MENA ${ }^{1}$ countries. However, in Africa, Asia, and Latin America as well as CEE ${ }^{2}$ countries, PPP did not seem relevant in the determination of the long-run behavior of the real exchange rate. Finally, they confirmed that the PPP concept should be rejected because PPP deviations are permanent.

S. Kasman, A. Kasman, and D. Ayhan (2010) tested the validity of the PPP theory on a sample of 11 countries of Central and Eastern Europe and three Mediterranean market economies $^{3}$ for the period from the beginning of 1990 until September 2006. They used LM unit root tests that included structural breaks in the data series. The results indicated that in cases of one and two structural breaks in the analysis of U.S. dollar-based real exchange rate series, there is stationarity only in Romania and Turkey. In the other cases, the series are

\footnotetext{
${ }^{1}$ The Middle East and North Africa (MENA) is an economically diverse region that includes both oil-rich economies in the Gulf and countries that are resource-scarce in relation to population. The MENA includes: Algeria, Bahrain, Djibouti, Egypt, Iran, Iraq, Israel, Jordan, Kuwait, Lebanon, Libya, Malta, Morocco, Oman, Qatar, Saudi Arabia, Syria, Tunisia, United Arab Emirates, West Bank and Gaza and Yemen.

${ }^{2}$ Central and Eastern European Countries (CEE) is an OECD term for the following group of countries: Albania, Bulgaria, Croatia, the Czech Republic, Hungary, Poland, Romania, the Slovak Republic, Slovenia, and the three Baltic States: Estonia, Latvia and Lithuania.

${ }^{3}$ Cyprus, Malta and Turkey.
} 
stationary for seven of the fourteen examining countries. Eventually, they applied a measure of persistence, the half-life of PPP deviations. Their results about half-life showed a wide range of half-life point estimates across countries.

In addition, Lyocsa, Baumohl and Vyrost, (2011) examined the need and the procedures of unit-root testing on a wider audience. They included four CEE countries ${ }^{4}$ from January 1973 to April 2009. They performed DF-GLS test and found that although they were unable to reject the unit root hypothesis, ARIMA model does not describe the non-stationary behavior of the series sufficiently and also that the true DGP (Data Generating Process) might be the one which is not integrated of order one.

A more recent study of Huang and Yang (2015), indicated that the flexibility of nominal exchange rate plays a key role in the adjustment of real exchange rates to PPP. Specifically, researchers applied the panel unit root test of Pesaran (2007) to real exchange rate data of eleven euro countries from 1957 to 2013 . They concluded to the fact that, the evidence for the mean-reverting in real exchange rates is much weaker in the post-1998 euro period than in the pre-euro period. Nevertheless, their findings showed that for the four countries not using the euro, the evidence for the mean-reverting in real exchange rates is strong in both periods.

In conclusion, existing empirical studies show that while the long-run PPP holds in some countries it does not in others. The literature further shows evidence that the adoption of sophisticated econometric models may provide a more accurate picture about the relevance of theoretical arguments in a real world setting. Along this line, this study intends to re-examine the validity of absolute PPP between emerging and advanced countries using more recent data and a variety of alternative tests in an attempt to identify all possible explanations for the resulting inferences.

\section{Empirical Data}

To assess our hypothesis, we use monthly data of eight exchange rates and monthly consumer price indices from OECD. All bilateral exchange rates have a common denominator, the US dollar. The time period under investigation is from August 1993 to August 2014.

\subsection{Empirical Analysis and Results}

In the first part of the empirical analysis, we employ two unit root tests (ADF and DF-GLS) and one stationarity test (KPSS) in order to investigate the existence of unit roots and determine the order of integration of the real exchange rates. If there is a unit root, we are unable to reject the hypothesis that PPP does not hold. Then, we apply the Johansen test which is the most fundamental test to investigate the long-run relationship between nominal exchange rate and consumer price index of each country, namely to check if our modeling has empirically meaningful relationships. Finally, we use a VAR model in order to extract firstly, the impulse response function to predict the movements of the variables, which are included in the PPP, due to shocks and secondly, variance decomposition to evaluate how shocks reverberate through a system.

\footnotetext{
${ }^{4}$ Slovakia, Czech Republic, Poland and Hungary.
} 


\section{Ml Macrothink}

Business and Economic Research

ISSN 2162-4860

2015, Vol. 5, No. 1

\subsubsection{Unit Root Test}

Before we proceed to test whether there is a cointegrating relationship between exchange rates and price levels, it is essential to test whether the real exchange rate series are non-stationary. Therefore, we perform unit root tests by including both a constant and a trend term ${ }^{5}$.

Following standard practice, we include lags, thus, in our case we use the Schwarz Information Criteria (SIC) in order to estimate the appropriate number of lags before proceeding to identify the probable order of stationarity. The results of the tests on the levels and the first differences are presented in table 1.

Table 1. Unit Root test: ADF, DF-GLS and KPSS in levels and first differences

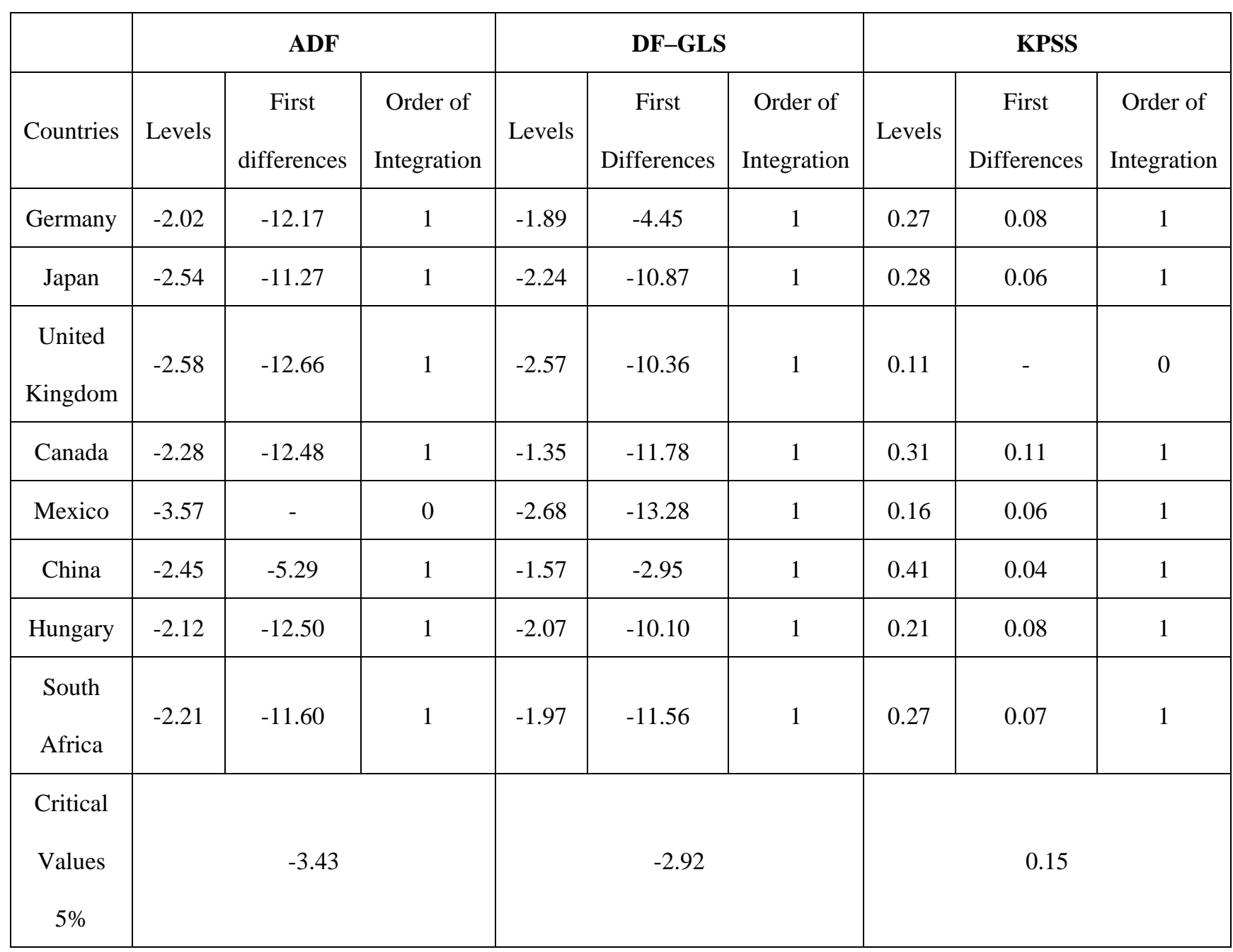

$\mathrm{ADF}^{6}$ results suggest that the null hypothesis cannot be rejected at the five percent level of significance and that all series are non-stationary in the levels, except for Mexico. The results of the DF-GLS ${ }^{7}$ tests are not fundamentally different from the respective ADF results apart

\footnotetext{
${ }^{5}$ Augmented-Dickey Fuller with intercept and trend: $q_{t}=\beta_{1}+\beta_{2} t+\gamma q_{t-1}+\Sigma_{i=1}^{p} \beta_{i} \Delta q_{t-1}+\varepsilon_{t}$

6 The null hypothesis is that the real exchange rate has a unit root.

7 The null hypothesis is that the real exchange rate has a unit root.
} 
from Mexico, therefore all country-series are non-stationary. Finally, the resulting $\mathrm{KPSS}^{8}$ test statistic takes values greater than the critical value at five percent level of significance with the only exception of the United Kingdom, thus, in all series the null hypothesis can be rejected except for the United Kingdom. Overall, the KPSS test rejects the null hypothesis, but ADF and DF-GLS do not, therefore all tests support the same conclusion (except for Mexico in ADF test and the United Kingdom in KPSS test, where PPP holds), namely the series are non-stationary in the levels, but they are stationary in the first differences, that is, they are integrated of order one.

\subsubsection{Half-Lives}

After formulating the unit root tests, it is important to calculate each country's half-life. The half-life of deviations from purchasing power parity (PPP) is used as a measure of persistence to quantify the degree of mean reversion in real exchange rates. It is defined as the number of years that it takes for deviations from PPP to subside permanently below 50 percent in response to a shock in the levels of the series. This particular notion of the degree of mean reversion in real exchange rates plays an important role in the ongoing debate about the ability of macroeconomic models to account for the time series behavior of the real exchange rate. The half-life, according to Christidou and Panagiotidis (2010) can be calculated as follows:

Half - life of the deviation from PPP $=\frac{\ln (0.5)}{\ln (1+\gamma)}$

where $\gamma$ is the coefficient of the lagged value in the regression model of the ADF test.

Table 2.

\begin{tabular}{|c|c|c|}
\hline Country & $\gamma$ & Half-lives (Years) \\
\hline Germany & -0.022101 & 2.58 \\
\hline Japan & -0.023736 & 2.40 \\
\hline United Kingdom & -0.041446 & 1.36 \\
\hline Canada & -0.008916 & 6.45 \\
\hline Mexico & -0.068511 & 0.81 \\
\hline China & -0.012578 & 4.56 \\
\hline Hungary & -0.010843 & 5.30 \\
\hline South Africa & -0.024219 & 2.35 \\
\hline
\end{tabular}

The half-lives from the $\mathrm{ADF}$ regressions ${ }^{9}$ for all samples are also presented in Table 2. The strongest evidence in favor of short half-lives is in Mexico (one year, due to its stationarity), the United Kingdom (one year), South Africa (two years) and Japan (two years). The weakest evidence is obtained in Germany, China, Hungary and Canada. This ranking casts doubt on

\footnotetext{
${ }^{8}$ The null hypothesis is that the real exchange rate is stationary.

9 Augmented Dickey - Fuller test with intercept: $\mathrm{q}_{\mathrm{t}}=\beta_{\mathrm{o}}+\gamma \mathrm{q}_{\mathrm{t}-1}+\Sigma_{\mathrm{i}=1}^{\mathrm{p}} \beta_{\mathrm{L}} \Delta \mathrm{q}_{\mathrm{t}-1}+\varepsilon_{\mathrm{t}}$
} 
explanations based on relative productivity growth, relative income growth or fiscal difficulties. Canada is a particularly interesting case. It has long been singled out for the apparent slow mean-reversion of its deviations from PPP. Also, it is worth noting that the half-life in Canada exceeds 6 years (6.45) and it is not different in other countries (Hungary 5.30 years and China 4.56 years). Thus, it is evident that the shortest the half-life, the quicker the adjustment to parity is.

In addition, we can compare the half-life estimates obtained in the present paper with those from previous research. Among several previous studies, Bergamelli (2014) estimated that half-life is two years in Germany and in the United Kingdom, one year in Mexico, five years in South Africa and six years in Japan. Another interesting study, of Kim, Silvapulle and Hyndman (2006) estimated that the half-life of Germany is one year, three years in Canada, two years in the United Kingdom and one year in Japan. Finally, the findings of Mladenovic et al. (2013) showed that the half-life of Hungary is about five years. Therefore, the estimated half-life here is approximately three years, which is in the range of three to five years as documented from the above studies and Rogoff's (1996).

\subsubsection{Cointegration Tests using Johansen Procedure}

To gain further insight into the issue, we examine the long-run equilibrium relation between the nominal exchange rate and the two price indices using the Johansen multivariate cointegration technique ${ }^{10}$. A necessary condition in order to investigate the cointegrating relationship between consumer price indices and exchange rates is that these variables must be integrated of order one. However, Japan, the United Kingdom, Canada, China and Hungary do not satisfy this requirement, thus, we examine the remaining countries for long-run relationship.

The issue of finding the appropriate lag length is very important, so we use the most common procedure by estimating the VAR model, inspecting the value of the Schwarz Information Criterion (SIC) and choosing the model that minimizes the SIC as the one with the optimal lag length. The Johansen cointegration test, then, has been conducted and the outcomes of the maximum eigenvalue and trace statistics are reported in Table 3. The cointegration tests yield conflicting results. In particular, it is shown that for both trace and maximum eigenvalue tests the hypothesis of two cointegrating vectors is not rejected for Mexican Peso exchange rate vis-a-vis US dollar. Nevertheless, test results of both trace and max-eigen statistics suggest none cointegrating vector for Germany and South Africa at the five percent level of significance.

We then proceed to estimate the vector error correction model (VECM) in order to analyze how short-run divergence, if any, was corrected so as to capture how rapidly long-run PPP is attained. Also, it should be noted that a necessary and sufficient condition for PPP to hold is that the logarithm of the exchange rate between countries and the logarithm of the price levels should be cointegrated with cointegrating vector [ $\left[\begin{array}{lll}1 & -1 & 1\end{array}\right]$. As we can see from table 3 , the p-value of Mexico is smaller than the five percent level of significance, so it does not

10 The Johansen model that has been used, allows for linear deterministic trend (intercept, no trend in CE and test VAR). 
satisfy the restrictions for the validity of PPP. As a consequence, the Johansen multivariate cointegration test concludes that the absolute PPP does not hold in any country.

Table 3. Johansen Cointegration Test Results

\begin{tabular}{|c|c|c|c|c|c|c|c|c|}
\hline \multirow[b]{2}{*}{ Country } & \multicolumn{4}{|c|}{ Trace Test } & \multicolumn{3}{|c|}{ Max-Eigen } & \multirow[b]{2}{*}{$\begin{array}{c}\text { P-values of } \\
\text { VECM }\end{array}$} \\
\hline & Lag & None & $\begin{array}{c}\text { At most } \\
1\end{array}$ & $\begin{array}{c}\text { At most } \\
2\end{array}$ & None & $\begin{array}{c}\text { At most } \\
1\end{array}$ & $\begin{array}{c}\text { At most } \\
2\end{array}$ & \\
\hline Germany & 2 & 12.80 & 3.25 & 0.51 & 9.55 & 2.74 & 0.51 & - \\
\hline Mexico & 2 & 52.08 & 19.52 & 0.82 & 32.56 & 18.71 & 0.82 & 0.007578 \\
\hline South Africa & 2 & 17.98 & 6.34 & 0.81 & 11.34 & 5.83 & 0.81 & - \\
\hline $\begin{array}{c}\text { Critical Values } \\
\text { (95\%) }\end{array}$ & & 29.80 & 15.50 & 3.84 & 21.13 & 14.26 & 3.84 & \\
\hline
\end{tabular}

3.1.4 Impulse Response Function from Domestic Price to Exchange Rate and to U.S. Price

The findings from the cointegration analysis are also reinforced with an alternative analysis, the impulse response function. The rationale beyond IRF is that it traces out the responsiveness of the dependent variables in the VAR model to shocks to the error term of each equation. For this purpose, we give a shock to the residuals of the VAR equations, to see how it affects the whole VAR model.

$$
\begin{gathered}
\mathrm{E}_{\mathrm{t}}=\alpha+\sum_{\mathrm{j}=1}^{\mathrm{k}} \beta_{\mathrm{j}} \mathrm{E}_{\mathrm{t}-\mathrm{j}}+\sum_{\mathrm{j}=1}^{\mathrm{k}} \beta_{\mathrm{j}} \mathrm{CPI}_{\mathrm{DOM}_{\mathrm{t}} \mathrm{t}-\mathrm{j}}+\sum_{\mathrm{j}=1}^{\mathrm{k}} \beta_{\mathrm{j}} \mathrm{CPI}_{\mathrm{USA}_{\mathrm{t}} \mathrm{t}-\mathrm{j}}+\mathrm{u}_{1 \mathrm{t}} \\
\mathrm{CPI}_{\mathrm{DOM}_{\mathrm{t}} \mathrm{t}}=\alpha+\sum_{\mathrm{j}=1}^{\mathrm{k}} \beta_{\mathrm{j}} \mathrm{E}_{\mathrm{t}-\mathrm{j}}+\sum_{\mathrm{j}=1}^{\mathrm{k}} \beta_{\mathrm{j}} \mathrm{CPI}_{\mathrm{DOM}_{\mathrm{t}} \mathrm{t}-\mathrm{j}}+\sum_{\mathrm{j}=1}^{\mathrm{k}} \beta_{\mathrm{j}} \mathrm{CPI}_{\mathrm{USA}_{\mathrm{t}} \mathrm{t}-\mathrm{j}}+\mathrm{u}_{2 \mathrm{t}} \\
\mathrm{CPI}_{\mathrm{USA}_{\mathrm{t}} \mathrm{t}}=\alpha+\sum_{\mathrm{j}=1}^{\mathrm{k}} \beta_{\mathrm{j}} \mathrm{E}_{\mathrm{t}-\mathrm{j}}+\sum_{\mathrm{j}=1}^{\mathrm{k}} \beta_{\mathrm{j}} \mathrm{CPI}_{\mathrm{DOM}_{2} \mathrm{t}-\mathrm{j}}+\sum_{\mathrm{j}=1}^{\mathrm{k}} \beta_{\mathrm{j}} \mathrm{CPI}_{\mathrm{USA}_{,} \mathrm{t}-\mathrm{j}}+\mathrm{u}_{3 \mathrm{t}}
\end{gathered}
$$

where $E_{t}$ is the nominal exchange rate defined in local currency units per foreign currency unit, $\mathrm{CPI}_{\mathrm{DOM}, \mathrm{t}}$ is the domestic consumer price index, $\mathrm{CPI}_{\mathrm{USA}, \mathrm{t}}$ is the foreign (USA) consumer price index and $\mathrm{u}_{\mathrm{i}, \mathrm{t}}$ are the residuals of each equation.

In the following charts (figure 1), we plot the 20-month impulse response functions of the nominal exchange rates and price levels, under different shocks to the eight countries which we examined previously. 
Response of LN_CAD_USD to Cholesky One S.D. Innovations

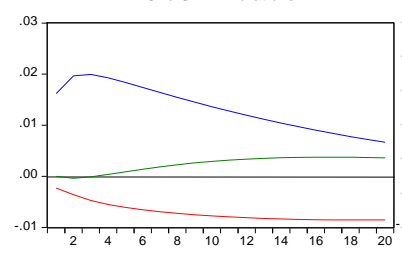

- LN_CAD_USD - LN_CANADA — LN_USA

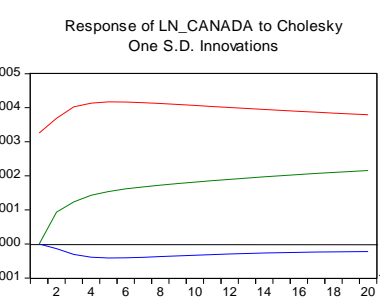

- LN_CAD_USD — LN_CANADA — LN_USA
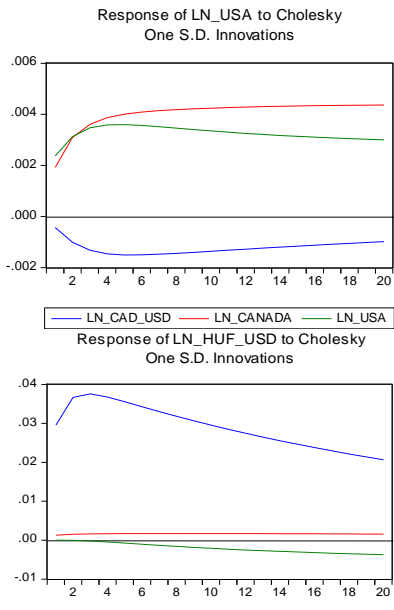

- LN_HUF_USD — LN_HUNG - LN_USA

Response of LN_HUNGARY to Cholesky One S.D. Innovations

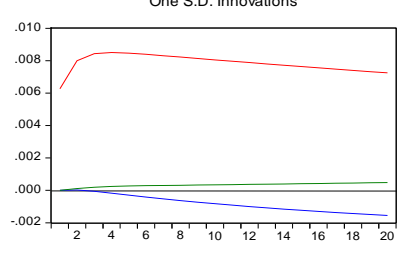

- LN_HUF_USD — LN_HUNG - LN_USA

Response of LN_USA to Cholesky

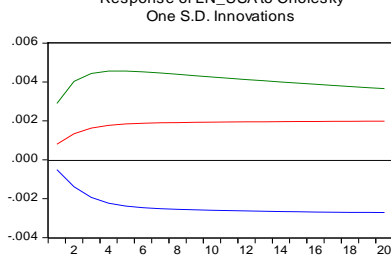

- LN_HUF_USD — LN_HUNG — LN_USA
Response of LN_CNY_USD to Cholesky

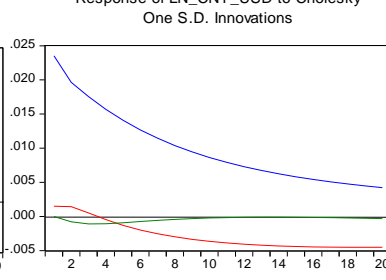

- LN_CNY_USD - LN_CHINA - LN_USA
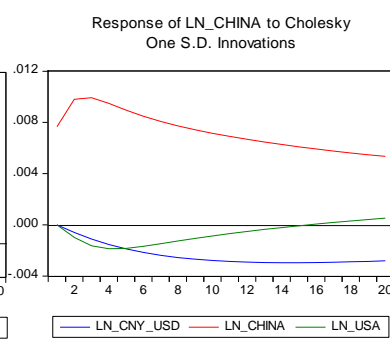

Response of LN_USA to Cholesky

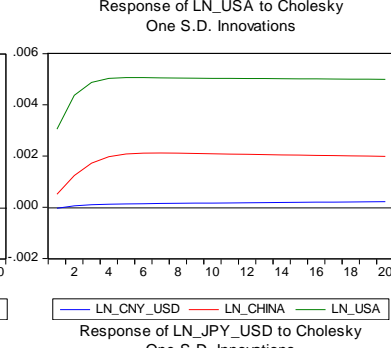

One S.D. Innovations
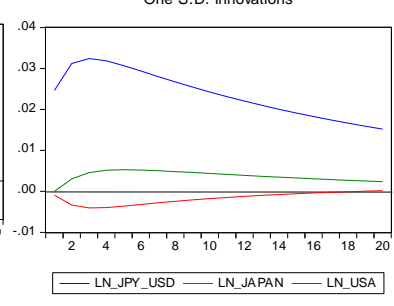

Response of LN_JAPAN to Cholesky

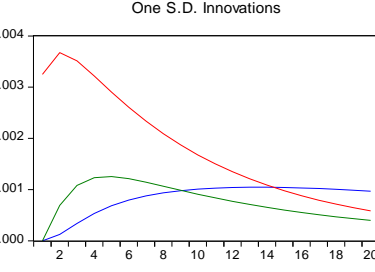

- LN_JPY_USD — LN_JAPAN — LN_USA

Response of LN_USA to Cholesky

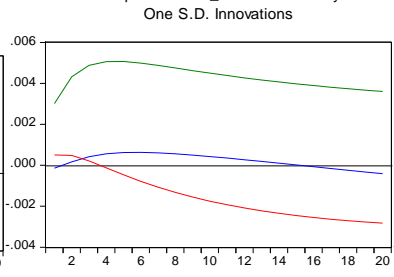

- LN_JPY_USD — LN_JAPAN — LN_USA

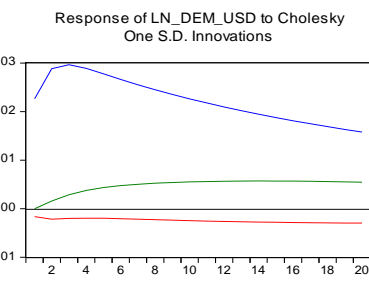

-LN_DEM_USD — LN_GERM —LN_USA

Response of LN_GERMANY to Cholesky One S.D. Innovations
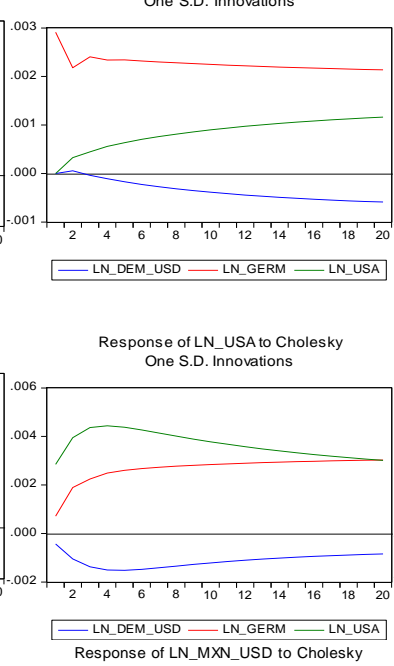

Response of LN_MXN_USD to Cholesky

$$
\text { One S.D. Innovations }
$$
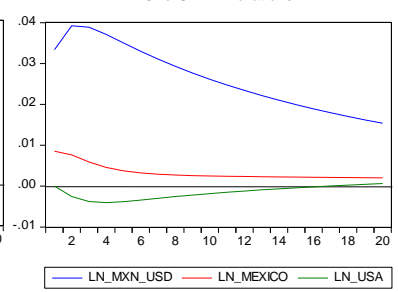

Response of LN_MEXICO to Cholesky One S.D. Innovations
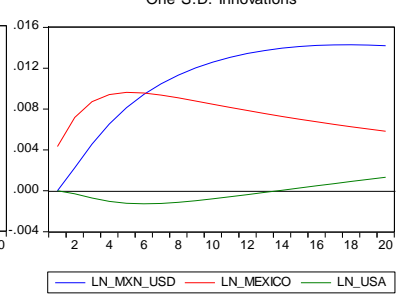

Response of LN_USA to Cholesky One S.D. Innovations

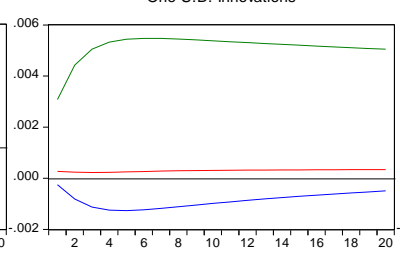

- LN_MXN_USD - LN_MEXICO _ LN_USA
2015, Vol. 5, No. 1

Response of LN_GBP_USD to Cholesky

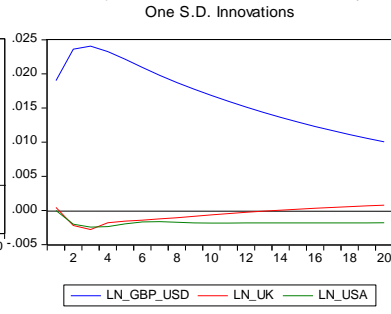

Response of LN_UK to Cholesky

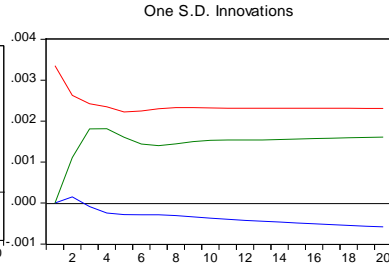

- LN_GBP_USD - LN_UK - LN_USA

Response of LN_USA to Cholesky One S.D. Innovations
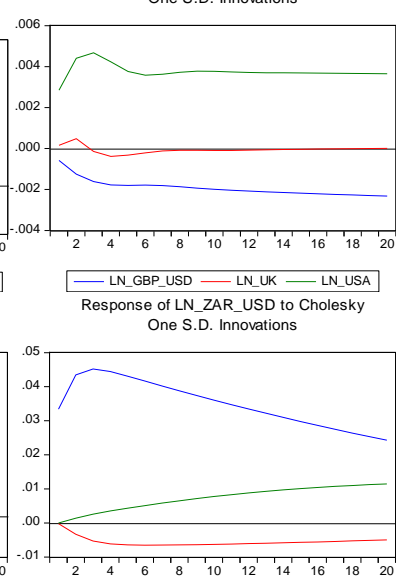

- LN_ZAR_USD - LN_AFRICA - LN_USA

Response of LN_AFRICA to Cholesky

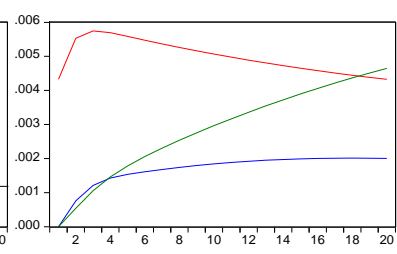

- LN_ZAR_USD — LN_AFRICA — LN_USA

Response of LN_USA to Cholesky

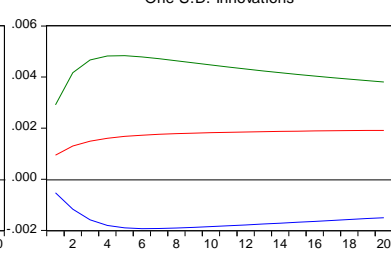

- LN_ZAR_USD - LN_AFRICA — LN_USA

Figure 1. Impulse Response Functions for Exchange Rate, Domestic Price and U.S. Price. Forecast origin and horizon are, respectively, 0 and from 1 to 20 months.

Initially, a shock to the US price leads to a real depreciation in the exchange rate and a decline in the price level of Canada in the long-run. In addition, a positive shock to the 
exchange rate induces a weak negative effect on the price level of the U.S.A. This result is in line with the absolute PPP hypothesis where these variables are inversely proportional. In the case of China, shocks to the price level of the U.S.A. have little impact on the exchange rate which appears to die out, suggesting mean reversion in the exchange rate. The impact of a positive shock to China's price level initially causes depreciation in the exchange rate whereas after the first four months it results in appreciation. Another attractive finding shows that a shock to the price index of the U.S.A. lowers China's price index, which becomes positive after sixteen months. Finally, there is almost no response of the U.S.A. price index to a shock to the exchange rate.

Following the same procedure, positive shocks to the price levels of Germany and the U.S.A. affect the nominal exchange rate in a negative as well as a positive way respectively. The exchange rate initially induces ambiguous results on Germany's consumer price but three months later it becomes negative. Furthermore, a shock to the CPI of Germany causes a strong positive effect to the consumer price index of the U.S.A.. As depicted in the graph, the response of the exchange rate to the United Kingdom's price level is positive in the first month and after the fourteenth month, however between these, it has a negative sign. Also, a given shock to the exchange rate results ambiguous findings, but three months later there follows a negative response of the United Kingdom's CPI. According to the point estimated of the impulse response, the price level of the U.S.A. is positive in the short-run, between the fourth and the thirteenth month it is negative and after that it remains unchanged.

When one standard deviation shock is given to the consumer price of the U.S.A. there are no significant effects to the exchange rate of Hungary for the first two months, however, in the remaining period it responses negatively. Moreover, a positive and steady response of the price index of Hungary is caused due to a positive shock to the price level of the U.S.A.. Additionally, as expected, a shock to the exchange rate induces a negative response to the price level of the U.S.A., which is according to the PPP theory. In the case of Japan, there is a strong negative response of the nominal exchange rate to the price level of the U.S.A., but this temporary effect vanishes after seventeen months. A positive shock to the consumer price index of the U.S.A. induces a dramatic increase in the consumer price index of Japan, and after five months it starts a steady increase. Finally, the effect of the exchange rate to the consumer price of the U.S.A. indicates a variety of outcomes. In particular, it affects it negatively in the first and after the sixteenth month and positively in the intermediate period.

We now turn to the response of the exchange rate of Mexico to the price of the U.S.A. which is initially negative, but it becomes positive after the seventeenth month. This implies that this pattern (after the eighteenth month) is inconsistent with the theory of the absolute PPP, due to the fact that while the price level of the U.S.A. increases, the exchange rate of Mexico rises too, namely there is an appreciation in the exchange rate of the U.S.A.. Also, from the impulse response of the exchange rate to the price index of Mexico, there is a rapid rise, and more specifically it reaches a peak, in the eighteenth month. The response of the price index of the U.S.A. to the price level of Mexico is steady for all the under examination period. Consumer price shocks have an overall negative impact on the exchange rate of South Africa. Moreover, the price level of the U.S.A. results in a positive and persistent effect on the price 


\section{Macrothink}

level of S. Africa. Finally, the impulse response functions indicate that the adjustment process of the US price level is not completed within these twenty months due to the various shocks to all of the variables.

\subsubsection{Variance Decomposition}

The second standard tool to analyze the properties of the estimated structural VAR is the variance decomposition. Variance decomposition offers a slightly different method to examine VAR system dynamics. It gives the proportion of the movement in the dependent variables that are due to their own shocks, versus shocks to the other variables. To further illustrate this point, a shock to one of the variables will directly affect its own, but it will also be transmitted to all of the other variables in the system through the dynamic structure of the VAR. Figure 2 presents the variance decomposition for each of the three variables for each country in the model over a 20-month forecast time horizon. The results from tables 4-11 indicate the variance decomposition of the nominal exchange rates, domestic consumer price indices and the consumer price index of the U.S.A. 


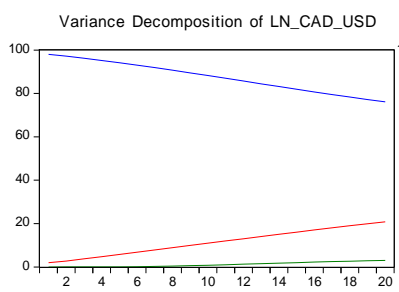

Variance Decomposition of LN_CNY_USD

Variance Decomposition of LN DEM USD

Variance Decomposition of LN_GBP_USD

- LN_CAD_USD — LN_CANADA — LN_USA
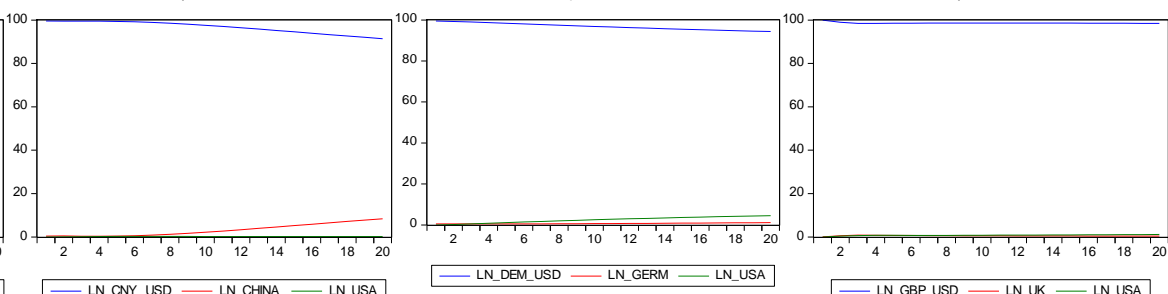

- LN_GBP_USD — LN_UK — LN_USA
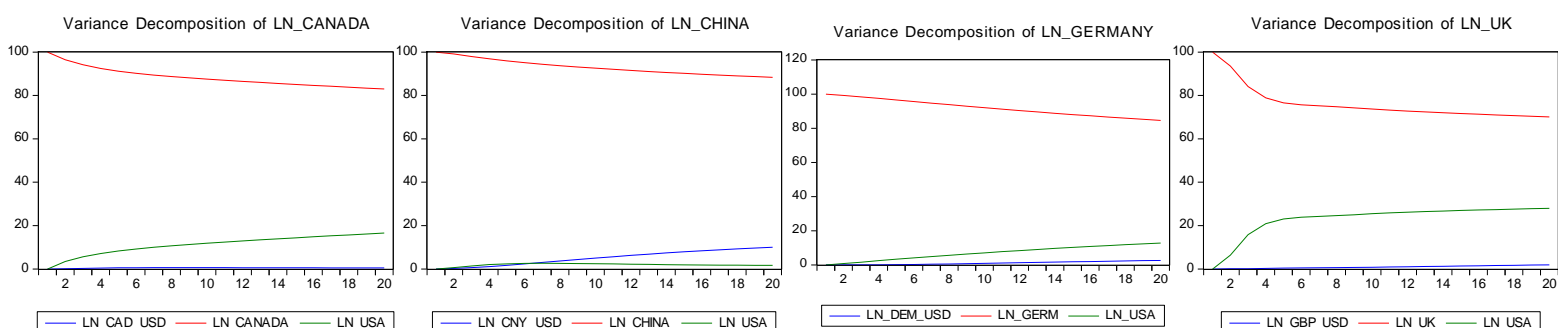

Variance Decomposition of LN_USA

Variance Decomposition of LN USA
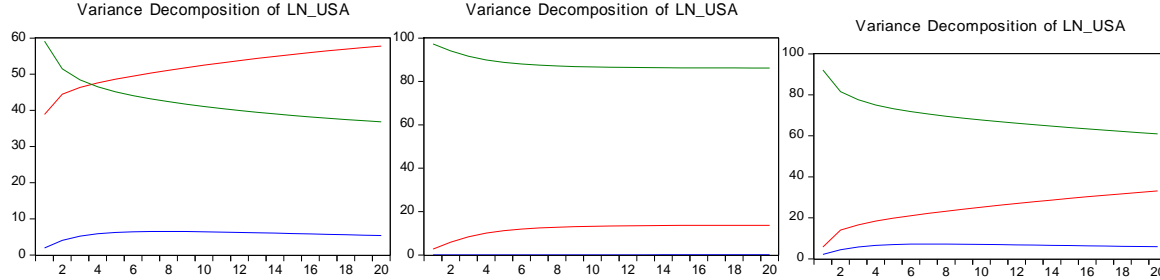

Variance Decomposition of LN USA
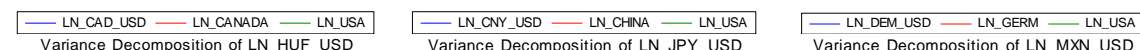

Variance Decomposition of LN_MXN USD
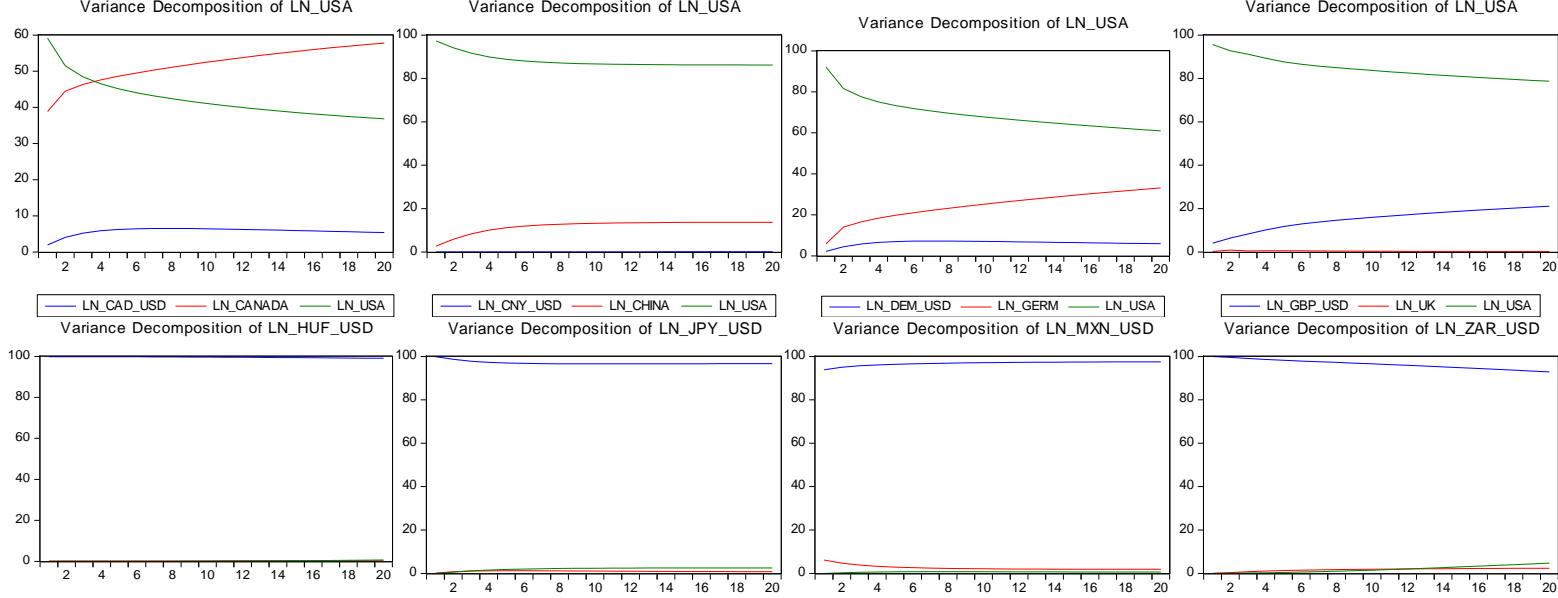

- LN_GBP_USD - LN_UK - LNUSA

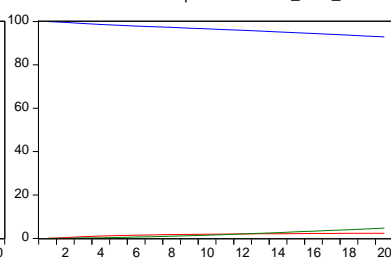

- LN_HUF_USD - LN_HUNG - LN_USA
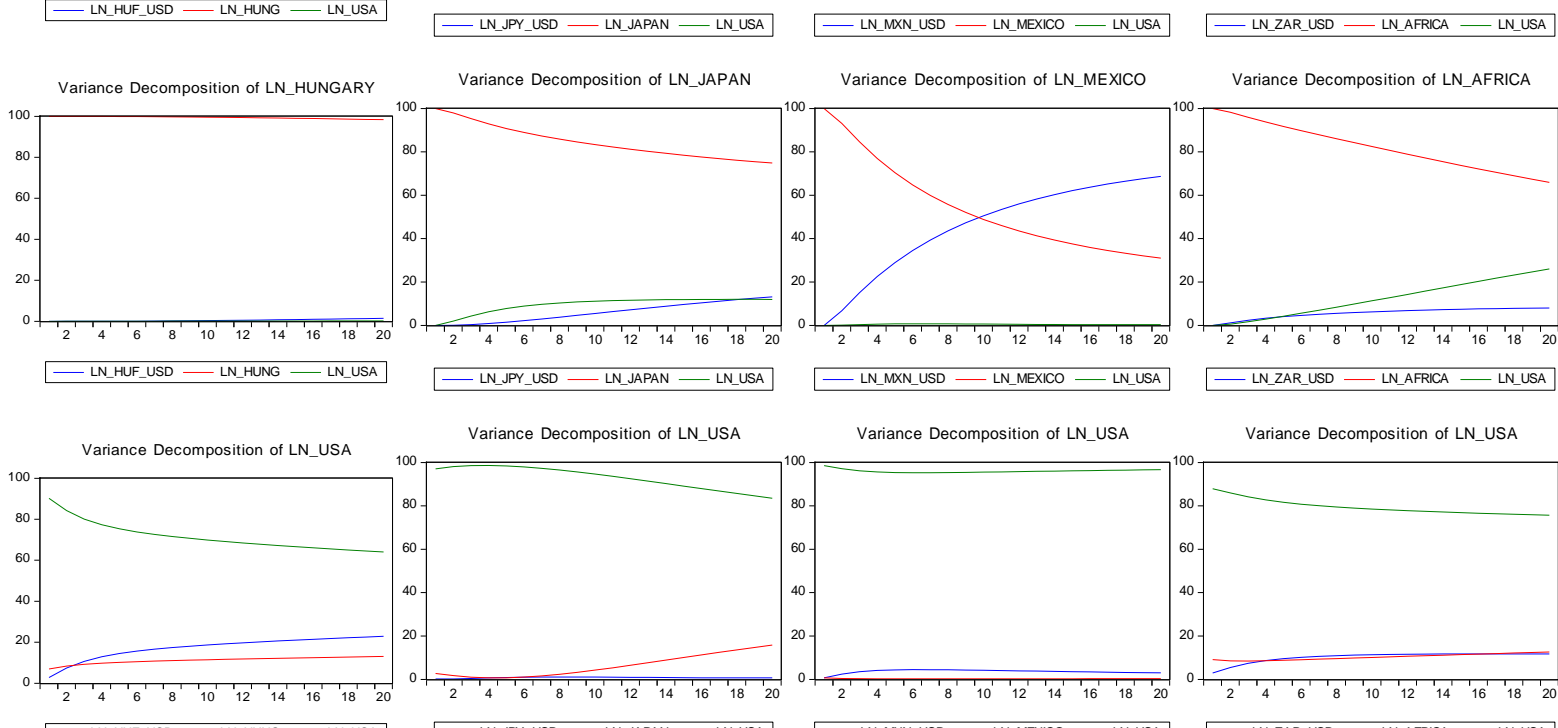

Variance Decomposition of LN_USA

Figure 2. Variance Decomposition for Exchange Rate, Domestic Price and U.S. Price.

Forecast origin and horizon are, respectively, 0 and from 1 to 20 months

We first examine the variance decomposition of the exchange rate, which shows that it depends mainly on itself (over 91 percent) in all countries except for Canada which, in the 
last period, accounts for 76 percent of the fluctuation. The variance of the exchange rate explained by the consumer price of Canada is equal to 21 percent. In addition, the variance of the consumer price that can be attributed to itself, demonstrates a dramatic fall in all countries (with Mexico as a characteristic example, which reaches the proportion of 31 percent in the twentieth period), apart from Hungary whose minimum value is 98 percent in the last month. The variance of the domestic price level that is explained by the exchange rate has a smooth increase or in some cases is equal to zero, except for Mexico which shoots up to 69 percent, over the percentage of the variance that is explained by Mexico's price level. Moreover, the variance of the domestic price level that can be attributed to the price level of the U.S.A. has a slight growth in most of the countries apart from Hungary and Mexico in which it is equal to zero.

The findings from the variance decomposition of the price index of the U.S.A. show that the proportion of the variance that is explained by itself is decreasing in all countries with the only exception of Mexico which explains the most (about 97 percent). Finally, the variance of the price level of the U.S.A. that can be attributed to the nominal exchange rates has a small rise, in contrast with the increasing percentage that is due to the price level of each country, while the economy of Canada constitutes a special case in which the proportion that is attributed to its price level is greater than the proportion that is explained by the price level of the U.S.A..

\section{Conclusion}

The purpose of this paper is to examine the long-run validity of the absolute PPP in eight developing and developed countries. Our discussion is concentrated on five broadly defined topics. Initially, we examine the stationarity of the real exchange rates using ADF, DF-GLS and KPSS tests and estimate the half-life of each country in comparison with the findings of previous studies. In addition, as a robustness check, we conduct a cointegration test, using the Johansen approach and finally we extract the impulse response function and the variance decomposition from the VAR.

Our empirical results indicate that the real exchange rates of the examined economies are all non-stationary except for Mexico in ADF test and the United Kingdom in KPSS test, where PPP is valid. The findings of the half-life estimates are striking and vary in comparison with the results of previous studies. More specifically, Mexico exhibits the highest speed of mean reversion of the real exchange rate, owing to its stationarity. With respect to the cointegration test between exchange rate and price levels, we found no evidence supporting a long-run relationship between these variables. Thus, due to the fact that Johansen test is more powerful than the previous ones, we conclude that long-run PPP does not hold for both developed and emerging countries. However, regarding the discrepancies of the above tests, we observe that our results are consistent with the work of Alba and Park (2003) and Acaravci S. K. and Acaravci A. (2007) who mentioned that the empirical validity of PPP remains a controversial and unsettled issue and thus further investigation is required.

An alternative way to assess the adjustment of the exchange rate and the price levels to an unexpected temporary shock is the impulse response function because it provides useful 
insight to interplay with PPP components. Our findings are in line with the existing literature except for the economy of Mexico which demonstrates an inconsistent picture with PPP predictions. Another notable finding is in the variance decomposition section where the variance of the U.S.A. price level is less explained by itself and more by the price level of Canada after the fourth month, which could be attributed to the fact that these two countries share the world's largest and most comprehensive trading relationship.

\section{References}

Abuaf, N., \& Jorion, P. (1990). Purchasing Power Parity in the Long Run. Journal of Finance. 45(1). 157-174. http://dx.doi.org/10.1111/j.1540-6261.1990.tb05085.x

Acaravci, S. K., \& Acaranvi, A. (2007). Purchasing Power Parity Under the Current Float. International Research Journal of Finance and Economics. 10. 167-174

Alba, J., \& Papell, D. (2007). Purchasing Power Parity and Country Characteristics: Evidence From Panel Data Tests. Journal of Development Economics, 83(1). 240-521. http://dx.doi.org/10.1016/j.jdeveco.2005.09.006

Bergamelli, M. (2014). Robust Estimation of Real Exchange Rate Process Half-Life. Unpublished Paper Presented at the 15th OxMetrics User Conference. London. United Kingdom. 4-5 September

Bhanja, N. Dar, A. Samantaraya, A. (2013). Doctrine of Purchasing Power Parity: An Analysis based on Cointegration and Wavelet regression. IOSR Journal of Humanity and Social Science. 7(4). 19-27. http://dx.doi.org/10.9790/0837-0741927

Caporale, M. G., \& Hanck, C. (2009). Cointegration Tests Of PPP: Do They Also Exhibit Erratic Behaviour?. Applied Economics Letters. 16(1). 9-15. http://dx.doi.org/10.1080/17446540802092198

Christidou, M., \& Panagiotidis, T. (2010). Purchasing Power Parity and the European Single Currency: Some New Evidence. Economic Modelling. $27 . \quad 1116-1123$. http://dx.doi.org/10.1016/j.econmod.2010.03.008

Drine, I. Rault, C. (2007). Purchasing Power Parity for Developing and Developed Countries: What Can We Learn from Non-Stationary Panel Data Models?. Cesifo Working Papers 2255. http://dx.doi.org/ 10.1111/j.1467-6419.2007.00548.x

Froot, K. A. \& Rogoff, K. (1995). Perspectives on PPP and Long-Run Real Exchange Rates. Handbook of International Economics. 3. 1647-1688. doi:10.1016/S1573-4404(05)80012-7

Huang, C. H. Yang, C. Y. (2015). European Exchange Rate Regimes and Purchasing Power Parity: An Empirical Study on Eleven Eurozone Countries. International Review of Economics and Finance. 35. 100-109. http://dx.doi.org/10.1016/j.iref.2014.09.008

Kasman, S. Kasman, A. Ayhan, D. (2010). Testing the Purchasing Power Parity Hypothesis for the New Member and Candidate Countries of the European Union: Evidence from Lagrange Multiplier Unit Root Tests with Structural Breaks. Emerging Markets Finance \& 
Trade. 46(2). 53-65. http://dx.doi.org/10.2753/REE1540-496X460204

Kim, J. S. Silvapulle, P. Hyndman, R. J. (2006). Half-Life Estimation on the Bias Corrected Bootstrap: A highest Density Region Approach. Working Paper 11-06. www.buseco.monash.edu.an/depts/ebs/puns/wpapers

Kojima, H. (2006). Impulse Responses of Exchange Rate and Prices under Purchasing Power Parity: Japanese Evidence from An extracted Inflation-Based Study. Finance Working Paper 11-06. UCLA Anderson School of Management Working Paper Series

Lyocsa, S. Vyrost, T. Baumohl, E. (2011). Unit-Root and Stationarity Testing with Empirical Application on Industrial Production of CEE-4 Countries. MPRA Paper 29648

McDonald, R. (1993). Long-Run Purchasing Power Parity: Is it for Real?. The Review of Economics and Statistics. 75(4). 690-695

Mkenda, B. K. (2001). An Empirical Test of Purchasing Power Parity in Selected African Countries-A Panel Data Approach. Working Papers No. 39. https://gupea.ub.gu.se/bitstream/2077/2677/1/gunwpe0039.pdf

Mladenovic, Z. Josifidis, K. Srdic, S. (2013). The Purchasing Power Parity in Emerging Europe: Empirical Results Based on Unit Root Tests with Two Breaks. Panoeconomicus. 60(2). 179-202. http://dx.doi.org/10.2298/PAN1302179M

Roggof, K. (1996). The Purchasing Power Parity Puzzle. Journal of Economic Literature. 34(2). 647-668

Salehizadeh, M., \& Taylor, R. (1999). A Test of Purchasing Power Parity for Emerging Economies. Journal of International Financial Markets, Institutions and Money. 9(2). 183-193. http://dx.doi.org/10.1016/S1042-4431(99)00006-2

Sarno, L., \& Valente, G. (2006). Deviation from purchasing power parity under different exchange rate regimes: Do they revert and, if so how?. Journal of Banking and Finance. 30(3). 3147-3169. http://dx.doi.org/10.1016/j.jbankfin.2005.12.007

Sekioua, H. S., \& Karanasos, M. (2006). The Real Exchange Rate and the PPP Puzzle: Further Evidence. Applied Financial Economics. 16. 199-211. http://dx.doi.org/10.1080/09603100500389945

Taylor, A. (1996). International Capital Mobility in History: Purchasing Power Parity in the Long - Run. NBER Working Paper Series. http://dx.doi.org/10.3386/w5742

Taylor, A., \& M. (2004). The Purchasing Power Parity Debate. NBER Working Paper Series. http://dx.doi.org/10.3386/w10607 
Appendix

Table 4

\begin{tabular}{|c|c|c|c|c|c|c|c|c|c|}
\hline & \multicolumn{3}{|c|}{$\begin{array}{c}\text { Variance Decomposition of } \\
\text { CAD/USD }\end{array}$} & \multicolumn{3}{c|}{$\begin{array}{c}\text { Variance Decomposition of } \\
\text { Canada's CPI }\end{array}$} & \multicolumn{3}{c|}{$\begin{array}{c}\text { Variance Decomposition of } \\
\text { USA's CPI }\end{array}$} \\
\hline Period & CAD/USD & CANADA & USA & CAD/USD & CANADA & USA & CAD/USD & CANADA & USA \\
\hline 1 & 98.00949 & 1.990505 & 0.000000 & 0.000000 & 100.0000 & 0.000000 & 1.957351 & 38.89475 & 59.14790 \\
\hline 3 & 96.25284 & 3.733405 & 0.013760 & 0.269705 & 94.14189 & 5.588404 & 5.188303 & 46.36865 & 48.44305 \\
\hline 11 & 86.97715 & 11.98876 & 1.034085 & 0.603595 & 86.99717 & 12.39923 & 6.342264 & 53.16042 & 40.49731 \\
\hline 20 & 76.11152 & 20.83953 & 3.048949 & 0.476689 & 82.98078 & 16.54253 & 5.384752 & 57.79241 & 36.82283 \\
\hline
\end{tabular}

Table 5

\begin{tabular}{|c|c|c|c|c|c|c|c|c|c|}
\hline & \multicolumn{3}{|c|}{$\begin{array}{c}\text { Variance Decomposition of } \\
\text { CNY/USD }\end{array}$} & \multicolumn{3}{c|}{$\begin{array}{c}\text { Variance Decomposition of } \\
\text { China's CPI }\end{array}$} & \multicolumn{3}{c|}{$\begin{array}{c}\text { Variance Decomposition of } \\
\text { USA's CPI }\end{array}$} \\
\hline Period & CNY/USD & CHINA & USA & CNY/USD & CHINA & USA & CNY/USD & CHINA & USA \\
\hline 1 & 99.59915 & 0.400855 & 0.000000 & 0.000000 & 100.0000 & 0.000000 & 0.014482 & 2.707202 & 97.27832 \\
\hline 3 & 99.49370 & 0.361091 & 0.145205 & 0.612604 & 97.98338 & 1.404013 & 0.025421 & 8.371644 & 91.60293 \\
\hline 11 & 97.05237 & 2.735459 & 0.212170 & 5.649380 & 92.03598 & 2.314642 & 0.065138 & 13.36537 & 86.56949 \\
\hline 20 & 91.42576 & 8.385004 & 0.189237 & 9.984267 & 88.36223 & 1.653499 & 0.097344 & 13.68139 & 86.22126 \\
\hline
\end{tabular}

Table 6

\begin{tabular}{|c|c|c|c|c|c|c|c|c|c|}
\hline & \multicolumn{2}{|c|}{$\begin{array}{c}\text { Variance Decomposition of } \\
\text { DEM/USD }\end{array}$} & \multicolumn{3}{c|}{$\begin{array}{c}\text { Variance Decomposition of } \\
\text { Germany's CPI }\end{array}$} & \multicolumn{3}{c|}{$\begin{array}{c}\text { Variance Decomposition of } \\
\text { USA's CPI }\end{array}$} \\
\hline Period & DEM/USD & GERM & USA & DEM/USD & GERM & USA & DEM/USD & GERM & USA \\
\hline 1 & 99.47310 & 0.526899 & 0.000000 & 0.000000 & 100.0000 & 0.000000 & 2.134126 & 5.740007 & 92.12587 \\
\hline 3 & 99.01802 & 0.507380 & 0.474597 & 0.022843 & 98.38550 & 1.591653 & 5.779048 & 16.56474 & 77.65621 \\
\hline 11 & 96.55819 & 0.677141 & 2.764668 & 1.071355 & 91.18798 & 7.740667 & 6.931224 & 26.11647 & 66.95230 \\
\hline 20 & 94.36071 & 1.127824 & 4.511467 & 2.628468 & 84.58858 & 12.78295 & 5.928276 & 33.11318 & 60.95855 \\
\hline
\end{tabular}

Table 7

\begin{tabular}{|c|c|c|c|c|c|c|c|c|c|}
\hline & \multicolumn{2}{|c|}{$\begin{array}{c}\text { Variance Decomposition of } \\
\text { GBP/USD }\end{array}$} & \multicolumn{2}{|c|}{$\begin{array}{r}\text { Variance Decomposition of United } \\
\text { Kingdom's CPI }\end{array}$} & \multicolumn{3}{c|}{$\begin{array}{c}\text { Variance Decomposition of } \\
\text { USA's CPI }\end{array}$} \\
\hline Period & GBP/USD & UK & USA & GBP/USD & UK & USA & GBP/USD & UK & USA \\
\hline 1 & 99.94566 & 0.054344 & 0.000000 & 0.000000 & 100.0000 & 0.000000 & 4.036452 & 0.284555 & 95.67899 \\
\hline 3 & 98.50058 & 0.843606 & 0.655811 & 0.105727 & 84.09304 & 15.80123 & 8.298920 & 0.507872 & 91.19321 \\
\hline 11 & 98.64698 & 0.529602 & 0.823416 & 0.918276 & 73.22054 & 25.86119 & 16.59125 & 0.312928 & 83.09582 \\
\hline 20 & 98.44819 & 0.432760 & 1.119053 & 1.927581 & 70.10565 & 27.96677 & 21.08105 & 0.173761 & 78.74519 \\
\hline
\end{tabular}

Table 8

\begin{tabular}{|c|c|c|c|c|c|c|c|c|c|}
\hline & \multicolumn{2}{|c|}{$\begin{array}{c}\text { Variance Decomposition of } \\
\text { HUF/USD }\end{array}$} & \multicolumn{2}{c|}{$\begin{array}{c}\text { Variance Decomposition of } \\
\text { Hungary's CPI }\end{array}$} & \multicolumn{2}{c|}{$\begin{array}{c}\text { Variance Decomposition of } \\
\text { USA's CPI }\end{array}$} \\
\hline Period & HUF/USD & HUNG & USA & HUF/USD & HUNG & USA & HUF/USD & HUNG & USA \\
\hline
\end{tabular}




\begin{tabular}{|c|c|c|c|c|c|c|c|c|c|}
\hline 1 & 99.80849 & 0.191510 & 0.000000 & 0.000000 & 100.0000 & 0.000000 & 2.804349 & 6.947885 & 90.24777 \\
\hline 3 & 99.81514 & 0.183469 & 0.001388 & 0.002049 & 99.96948 & 0.028475 & 10.67046 & 9.226320 & 80.10322 \\
\hline 11 & 99.59860 & 0.242830 & 0.158573 & 0.415599 & 99.47400 & 0.110402 & 19.20287 & 11.64850 & 69.14863 \\
\hline 20 & 99.06053 & 0.306413 & 0.633056 & 1.454438 & 98.35188 & 0.193684 & 22.89545 & 13.07783 & 64.02672 \\
\hline
\end{tabular}

Table 9

\begin{tabular}{|c|c|c|c|c|c|c|c|c|c|}
\hline & \multicolumn{3}{|c|}{$\begin{array}{c}\text { Variance Decomposition of } \\
\text { JPY/USD }\end{array}$} & \multicolumn{3}{c|}{$\begin{array}{c}\text { Variance Decomposition of } \\
\text { Japan's CPI }\end{array}$} & \multicolumn{3}{c|}{$\begin{array}{c}\text { Variance Decomposition of } \\
\text { USA's CPI }\end{array}$} \\
\hline Period & JPY/USD & JAPAN & USA & JPY/USD & JAPAN & USA & JPY/USD & JAPAN & USA \\
\hline 1 & 99.85567 & 0.144330 & 0.000000 & 0.000000 & 100.0000 & 0.000000 & 0.212004 & 2.731227 & 97.05677 \\
\hline 3 & 97.81567 & 1.059346 & 1.124985 & 0.340108 & 95.34660 & 4.313287 & 0.417356 & 1.020344 & 98.56230 \\
\hline 11 & 96.57560 & 1.007018 & 2.417383 & 6.334388 & 82.26058 & 11.40503 & 1.016315 & 5.360990 & 93.62269 \\
\hline 20 & 96.71391 & 0.773744 & 2.512348 & 13.17537 & 74.84726 & 11.97738 & 0.679183 & 15.81737 & 83.50345 \\
\hline
\end{tabular}

Table 10

\begin{tabular}{|c|c|c|c|c|c|c|c|c|c|}
\hline & \multicolumn{3}{|c|}{$\begin{array}{c}\text { Variance Decomposition of } \\
\text { MXN/USD }\end{array}$} & \multicolumn{3}{c|}{$\begin{array}{r}\text { Variance Decomposition of } \\
\text { Mexico's CPI }\end{array}$} & \multicolumn{3}{c|}{$\begin{array}{c}\text { Variance Decomposition of } \\
\text { USA's CPI }\end{array}$} \\
\hline Period & MXN/USD & MEXICO & USA & MXN/USD & MEXICO & USA & MXN/USD & MEXICO & USA \\
\hline 1 & 93.83523 & 6.164766 & 0.000000 & 0.000000 & 100.0000 & 0.000000 & 0.682707 & 0.736592 & 98.58070 \\
\hline 3 & 95.69530 & 3.828286 & 0.476412 & 15.04653 & 84.61230 & 0.341166 & 3.508425 & 0.312571 & 96.17900 \\
\hline 11 & 97.22375 & 2.040771 & 0.735484 & 53.44053 & 46.02124 & 0.538220 & 4.058974 & 0.267129 & 95.67390 \\
\hline 20 & 97.53279 & 1.870102 & 0.597111 & 68.66187 & 30.97843 & 0.359708 & 2.993734 & 0.325240 & 96.68103 \\
\hline
\end{tabular}

Table 11

\begin{tabular}{|c|c|c|c|c|c|c|c|c|c|}
\hline \multirow[b]{2}{*}{ Period } & \multicolumn{3}{|c|}{$\begin{array}{c}\text { Variance Decomposition of } \\
\text { ZAR/USD }\end{array}$} & \multicolumn{3}{|c|}{$\begin{array}{c}\text { Variance Decomposition of South } \\
\text { Africa's CPI }\end{array}$} & \multicolumn{3}{|c|}{$\begin{array}{c}\text { Variance Decomposition of } \\
\text { USA's CPI }\end{array}$} \\
\hline & ZAR/USD & $\begin{array}{c}\text { S. } \\
\text { AFRICA }\end{array}$ & USA & ZAR/USD & S. AFRICA & & ZAR/USD & $\begin{array}{c}\text { S. } \\
\text { AFRICA }\end{array}$ & USA \\
\hline 1 & 99.99687 & 0.003134 & 0.000000 & 0.000000 & 100.0000 & 0000000 & 2.931757 & 9.154032 & 87.91421 \\
\hline 3 & 99.06092 & 0.768022 & & & & & & 8.456314 & 84.16700 \\
\hline 11 & 96.26241 & 1.980427 & 1.757162 & 6.532693 & 80.66706 & 12.80025 & 11.47905 & 10.38880 & 78.13215 \\
\hline 20 & 92.89345 & 2.367574 & 4.738977 & 7.994446 & 65.95576 & 26.04979 & 11.69239 & 12.61751 & 75.69010 \\
\hline
\end{tabular}

\section{Copyright Disclaimer}

Copyright for this article is retained by the author(s), with first publication rights granted to the journal.

This is an open-access article distributed under the terms and conditions of the Creative Commons Attribution license (http://creativecommons.org/licenses/by/3.0/). 